\title{
Augmentation of Yield Parameters and Yield through Zinc and Green Leaf Manuring on Lowland Rice
}

\author{
P. Prakash ${ }^{1 *}$, M. Hemalatha ${ }^{2}$ and M. Joseph ${ }^{3}$ \\ ${ }^{1}$ Department of Agronomy, Agricultural College and Research Institute, Madurai, \\ TNAU, Tamil Nadu, 625104, India \\ ${ }^{2}$ Department of Agronomy, Agricultural College and Research Institute, Killikulam, \\ TNAU, Tamil Nadu, 628252, India \\ ${ }^{3}$ Agricultural Research Station, Kovilpatti, TNAU, Tamil Nadu, 628501, India \\ *Corresponding author
}

A B S T R A C T

Keywords

Rice, Zinc, Green leaf manure, Yield parameters, Yield.

Article Info

Accepted:

17 June 2017

Available Online:

10 July 2017
Field experiment was conducted at Agricultural College and Research Institute, Killikulam, TNAU, Tamil Nadu, during late Pishanam season (November - March) of 2015 - 2016, to study the effect of zinc and green leaf manuring on yield parameters and yield of rice. The experiment was laid out in randomized block design replicated thrice using rice ADT (R) 45 as a test variety. The yield parameters like number of productive tillers hill ${ }^{-1}$, panicle length $(\mathrm{cm})$, panicle weight $(\mathrm{g})$, number of filled and ill filled grains panice $^{-1}$, sterility percentage and test grain weight were recorded. The treatment which receives, 100\% RDF+ GLM @6.25 t/ha + $\mathrm{ZnSO}_{4} @ 12.5$ $\mathrm{kg} / \mathrm{ha}$ as basal + Foliar spray of $\mathrm{ZnSO}_{4} @ 1.0 \%$ recorded the higher yield parameters and yield of rice. However it was at par with the application of $100 \%$ RDF + GLM @6.25 t / ha + ZnSO 4 @ $12.5 \mathrm{~kg} /$ ha as basal + Foliar spray of $\mathrm{ZnSO}_{4} @ 0.5 \%$.

\section{Introduction}

Rice is the predominant and stable food grain crop for millions of people, which is grown in many countries of the world. In recent past, chemical fertilizers have played a very significant role in providing nutrients for intensive cropping, with high yielding varieties, which heralded the green revolution in the country. Fertilizer is very important input for intensive rice production and the profitability of rice production systems. So the appropriate fertilizer is not only for getting higher grain yield but also for attaining maximum profitability.

Among the fertilizer, micronutrients play key role in quantitative and qualitative aspects of crop production. Their deficiency has an adverse effect on yield and quality of crops. For sustaining high productivity and quality of the produce it is essential to ensure that crop plants are adequately supplied with micronutrients. Among the seven 
micronutrients, zinc is considered to be the most important nutrient next to $\mathrm{N}, \mathrm{P}$ and $\mathrm{K}$ in throughout the world.

In present day agriculture micronutrients play an important role to enhance the agricultural productivity (Mustafa et al., 2011) and their deficiency is considered as one of the major causes of the declining productivity trends observed in rice growing countries (Savithri et al., 1999). To meet the food demands of the growing population and to achieve food security in the country, the present production level needs to be increased by two million tonnes in every year. Application of $\mathrm{Zn}$ fertilizer is a common agricultural practice in lowland rice production to correct $\mathrm{Zn}$ deficiency and increase grain yield (Dobermann and Fairhust, 2000).

Green leaf manuring is one of the important practices for increasing organic matter content in the soil. Green leaf manuring was successfully adopted to improve the soil productivity. Gliricidia green leaf manuring which improved the physical and chemical properties of soil due to its decomposition and in turn increased the availability of adequate $\mathrm{N}$ during the later growth period of the crop and thereby promoted the translocation of assimilates to sink resulting in higher panicle weight (Damodaran et al., 2014).

\section{Materials and Methods}

A field experiment was conducted at Agricultural College and Research Institute, Killikulam, TNAU during late Pishanam season (November - March) of 2015-2016. The farm is geographically located in the southern part of Tamil Nadu at $8^{\circ} 46^{\prime} \mathrm{N}$ latitude and $77^{\circ} 42^{\prime} \mathrm{E}$ longitude at an altitude of $40 \mathrm{~m}$ above mean sea level.

The experimental site is situated in semi-arid tropical region. The mean annual rainfall is
$786.6 \mathrm{~mm}$ received in 40 rainy days. The mean maximum and minimum temperature of the location were $33.4{ }^{\circ} \mathrm{C}$ and $23.6{ }^{\circ} \mathrm{C}$ respectively. The soil of the experimental field is sandy clay loam in texture. The fertility status was low in available nitrogen $\left(237 \mathrm{~kg} \mathrm{ha}{ }^{-1}\right)$, medium in available phosphorus (18 kg ha $\left.{ }^{-1}\right)$, medium in available potassium $\left(240 \mathrm{~kg} \mathrm{ha}^{-1}\right)$, Organic carbon (0.64 $\%), \mathrm{pH}$ (1:2 soil water suspension) (7.4) and diethylene triaminepenta acetic acid (DTPA) extractable $\mathrm{Zn}$ in soil was $0.8 \mathrm{mg} \mathrm{kg}^{-1}$ of soil.

The experiment was laid out in randomized block design, replicated thrice using ADT (R) 45 as the test variety. The prime objective of the experiment was to study the effect of zinc and green leaf manuring on yield parameters and yield of rice. To fulfill the objective, the experiment was carried out with the following treatments i.e. $100 \%$ RDF alone $\left(\mathrm{T}_{1}\right)$ and it was in combination with $\mathrm{ZnSO}_{4}$ @ $25.0 \mathrm{~kg} /$ ha as basal $\left(\mathrm{T}_{2}\right), 37.5 \mathrm{~kg} / \mathrm{ha}$ as basal $\left(\mathrm{T}_{3}\right)$, $\mathrm{ZnSO}_{4} @ 0.5 \%$ as foliar spray $\left(\mathrm{T}_{4}\right), 1.0 \%$ as foliar spray $\left(\mathrm{T}_{5}\right)$.

The treatment $\mathrm{T}_{6}$ to $\mathrm{T}_{8}$ consist of $100 \% \mathrm{RDF}$ + GLM@6.25 t/ha+ $\mathrm{ZnSO}_{4} @ 12.5 \mathrm{~kg} / \mathrm{ha}$ as basal $\left(\mathrm{T}_{6}\right), 25.0 \mathrm{~kg} / \mathrm{ha}$ as basal $\left(\mathrm{T}_{7}\right)$ and $37.5 \mathrm{~kg} / \mathrm{ha}$ as basal $\left(\mathrm{T}_{8}\right)$.

For treatment $T_{9}$ and $T_{10}$ instead of basal application, the $\mathrm{ZnSO}_{4}$ was given as $0.5 \%$ foliar spray $\left(\mathrm{T}_{9}\right)$ and $1.0 \%$ foliar spray $\left(\mathrm{T}_{10}\right)$ with 100\% RDF + GLM @ 6.25 t/ha. The treatment $\mathrm{T}_{11}$ and $\mathrm{T}_{12}$ consist of all combination in 100\% RDF + GLM @6.25 t / ha+ $\mathrm{ZnSO}_{4} @ 12.5 \mathrm{~kg}$ as basal + 0.5\% $\mathrm{ZnSO}_{4}$ as foliar spray $\left(\mathrm{T}_{11}\right)$ and $1.0 \%$ foliar spray $\left(\mathrm{T}_{12}\right)$.

The recommended dose of fertilizer viz., 150:50:50 kg N, $\mathrm{P}_{2} \mathrm{O}_{5}$ and $\mathrm{K}_{2} \mathrm{O}$ ha $^{-1}$ was applied to all the plots. The entire $\mathrm{P}$ fertilizer was applied as basal in the form of 
Diammonium phosphate $(18 \% \mathrm{~N}$ and $46 \%$ $\mathrm{P}_{2} \mathrm{O}_{5}$ ).

The $\mathrm{N}$ fertilizer was applied in the form of urea $(46 \% \mathrm{~N})$ and applied in four equal splits viz., one at basal and remaining at active tillering, panicle initiation and heading stages. The basal dose $\mathrm{N}$ was adjusted with $\mathrm{N}$ supplied by DAP. The $\mathrm{K}$ fertilizer was applied in the form of Muriate of Potash (60 $\% \mathrm{~K}_{2} \mathrm{O}$ ) in four equal splits viz., one at basal and remaining at active tillering, panicle initiation and heading stages along with $\mathrm{N}$.

Leaves and twigs of Glyricidia maculate @ $6.25 \mathrm{t} \mathrm{ha}^{-1}$ was collected from the farm and incorporated in the respective plots at ten days before transplanting. After incorporation the field was puddled two times and leveled two days prior to planting.

Zinc sulphate $12.5,25,37.5 \mathrm{~kg} / \mathrm{ha}$ was mixed with sand to uniform distribution and applied as basal before the transplanting to the respective plots as per the treatment. Zinc sulphate at 0.5 and $1 \%$ foliar spray was given in two times viz., at active tillering and panicle initiation. The yield parameters like number of productive tillers hill ${ }^{-1}$, panicle length $(\mathrm{cm})$, panicle weight $(\mathrm{g})$, number of filled grains and ill filled grains panice ${ }^{-1}$, Sterility percentage, test grain weight and yield (grain and straw) were recorded.

\section{Results and Discussion}

\section{Yield parameters of rice (Tables 1 and 2)}

Yield parameters of rice favorably increased with the application of zinc through soil plus foliar with green leaf manuring. Results obtained from the experiment, among the various nutrient management practices the yield attributes (productive tillers hill $^{-1}$, panicle length, panicle weight and total number of filled grains panicle ${ }^{-1}$ ) showed an impressive improvement under the application of 100\% RDF + GLM @ $6.25 \mathrm{t} /$ ha+ $\mathrm{ZnSO}_{4} @ 12.5 \mathrm{~kg} /$ ha as basal + Foliar spray of $\mathrm{ZnSO}_{4} @ 1.0 \%$.

Application of RDF with/without zinc sulphate foliar spray @ 0.5 and 1\% had depressed all the growth attributing characters and consequently on yield components also baring ill filled grains panicle ${ }^{-1}$. Adoption of $\mathrm{RDF}+$ green leaf manure + zinc sulphate @ $12.5 \mathrm{~kg} / \mathrm{ha}$ as basal $+1 \%$ as foliar spray at tillering and panicle initiation stage produced higher number of productive tillers hill ${ }^{-1}$, panicle length, panicle weight, total number of filled grains panicle ${ }^{-1}, 1000$ grain weight and less sterility percentage (Fig. 1).

Number of productive tillers per hill $^{-1}$ contributes towards the production potential of rice crop. Increase in productive tillers (28 per hill ${ }^{-1}$ ) might be ascribed to adequate supply of zinc that might had increased the uptake and availability of other essential nutrients, which resulted in improvement of plant metabolic process and finally increased the crop growth.

These results are in accordance with Naik and Das (2007); who reported that adequate supply of zinc produced more number of productive tillers per hill $^{-1}$. As various methods of zinc nutrition, basal plus foliar application of zinc at the rate of $12.5 \mathrm{~kg} \mathrm{ha}^{-1}+$ foliar application of $0.5 \%\left(\mathrm{~T}_{11}\right)$ and $1.0 \%$ $\left(\mathrm{T}_{12}\right)$ with green leaf manuring and $37.5 \mathrm{~kg}$ $\mathrm{ha}^{-1}$ as basal produced statistically similar panicle lengths $24.0,25.48$ and $23.70 \mathrm{~cm}$, respectively.

Yield is directly related with number of filled grains per panicle. Data showed that filled grains per panicle were significantly increased with zinc application over control. These results were in accordance with Arif et al., (2006) who reported that foliar application of micronutrients increased spikelets per spike. 
Table.1 Effect of zinc and green leaf manuring on productive tillers, Panicle length, panicle weight and test grain weight of rice

\begin{tabular}{|c|c|c|c|c|}
\hline Treatment & $\begin{array}{c}\text { No. of } \\
\text { productive tillers } \\
\text { hill }^{-1}\end{array}$ & $\begin{array}{c}\text { Panicle } \\
\text { length }\end{array}$ & $\begin{array}{c}\text { Panicle } \\
\text { weight }\end{array}$ & $\begin{array}{c}\text { Test grain } \\
\text { weight }\end{array}$ \\
\hline $\mathrm{T}_{1}$ & 20 & 18.00 & 2.0 & 17.16 \\
\hline $\mathrm{T}_{2}$ & 22 & 20.33 & 2.3 & 17.32 \\
\hline $\mathrm{T}_{3}$ & 22 & 21.00 & 2.3 & 17.38 \\
\hline $\mathrm{T}_{4}$ & 21 & 19.50 & 2.1 & 17.24 \\
\hline $\mathrm{T}_{5}$ & 22 & 19.67 & 2.2 & 17.27 \\
\hline $\mathrm{T}_{6}$ & 24 & 22.60 & 2.8 & 17.62 \\
\hline $\mathrm{T}_{7}$ & 24 & 23.04 & 3.0 & 17.68 \\
\hline $\mathrm{T}_{8}$ & 25 & 23.70 & 3.1 & 17.73 \\
\hline $\mathrm{T}_{9}$ & 23 & 21.54 & 2.5 & 17.45 \\
\hline $\mathrm{T}_{10}$ & 23 & 22.10 & 2.6 & 17.56 \\
\hline $\mathrm{T}_{11}$ & 26 & 24.00 & 3.4 & 17.76 \\
\hline $\mathrm{T}_{12}$ & 28 & 25.48 & 3.6 & 17.83 \\
\hline $\mathrm{SE} \mathrm{d}$ & 0.77 & 1.01 & 0.20 & 0.24 \\
$\mathrm{CD}(\mathrm{P}=0.05$ & 1.61 & 2.10 & 0.43 & $\mathrm{NS}$ \\
\hline$)$ & & & & \\
\hline
\end{tabular}

Table.2 Effect of zinc and green leaf manuring on filled grains and ill Filled grains and sterility percentage of rice

\begin{tabular}{|c|c|c|c|}
\hline Treatment & $\begin{array}{c}\text { No. of filled grains } \\
\text { panicle }^{-1}\end{array}$ & $\begin{array}{c}\text { No. of ill filled grains } \\
\text { panicle }^{-1}\end{array}$ & $\begin{array}{c}\text { Sterility } \\
\text { percentage }\end{array}$ \\
\hline $\mathrm{T}_{1}$ & 113 & 25 & 18 \\
\hline $\mathrm{T}_{2}$ & 145 & 21 & 13 \\
\hline $\mathrm{T}_{3}$ & 151 & 20 & 11 \\
\hline $\mathrm{T}_{4}$ & 121 & 24 & 16 \\
\hline $\mathrm{T}_{5}$ & 132 & 23 & 15 \\
\hline $\mathrm{T}_{6}$ & 164 & 16 & 9 \\
\hline $\mathrm{T}_{7}$ & 169 & 14 & 8 \\
\hline $\mathrm{T}_{8}$ & 175 & 12 & 6 \\
\hline $\mathrm{T}_{9}$ & 155 & 19 & 11 \\
\hline $\mathrm{T}_{10}$ & 161 & 17 & 10 \\
\hline $\mathrm{T}_{11}$ & 179 & 10 & 5 \\
\hline $\mathrm{T}_{12}$ & 183 & 9 & 0.69 \\
\hline $\mathrm{SE} \mathrm{d}$ & 4.71 & 1.26 & 1.44 \\
\hline $\mathrm{CD}(\mathrm{P}=0.05)$ & 9.77 & 2.63 & 5 \\
\hline
\end{tabular}


Fig.1 Effect of zinc and green leaf manuring on number of filled grains, ill filled grains panicle ${ }^{-1}$ and sterility percentage

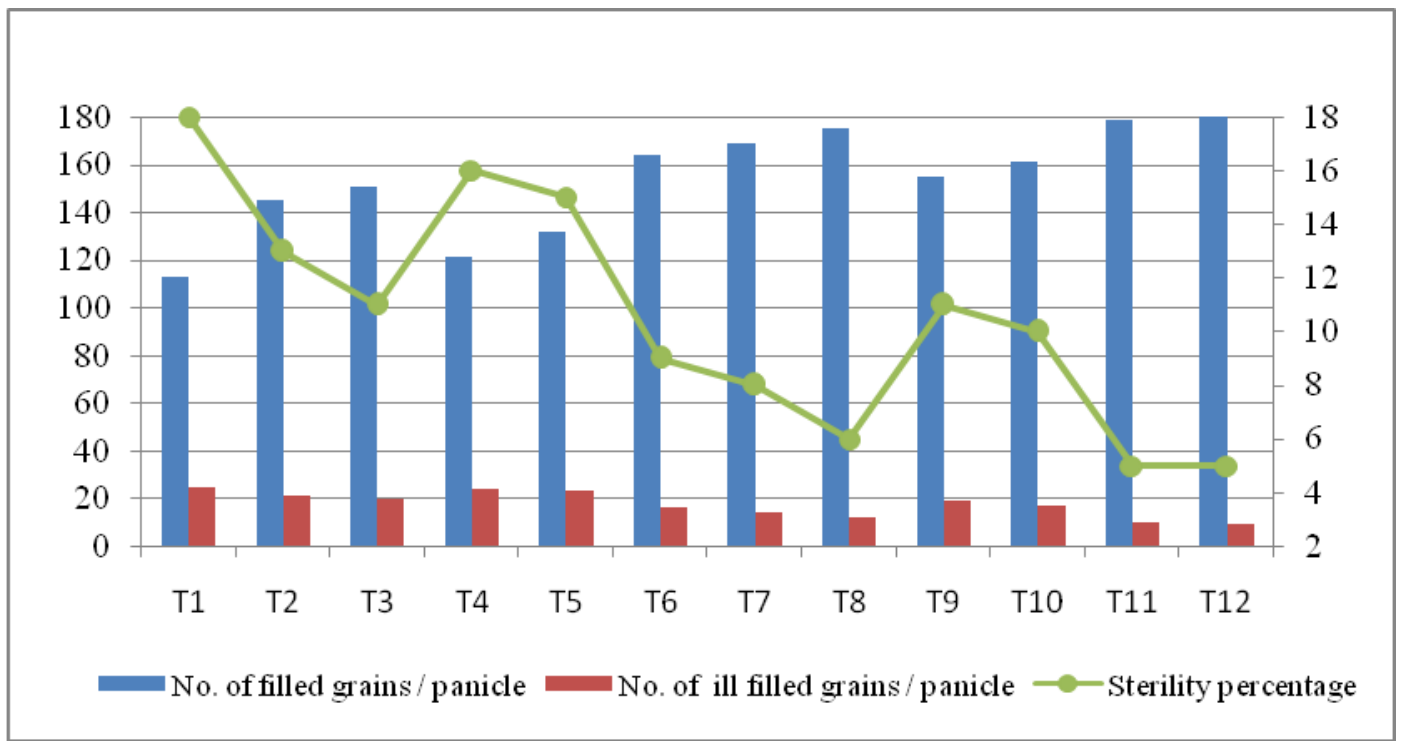

Fig.2 Effect of zinc and green leaf manuring on grain and straw yield of rice

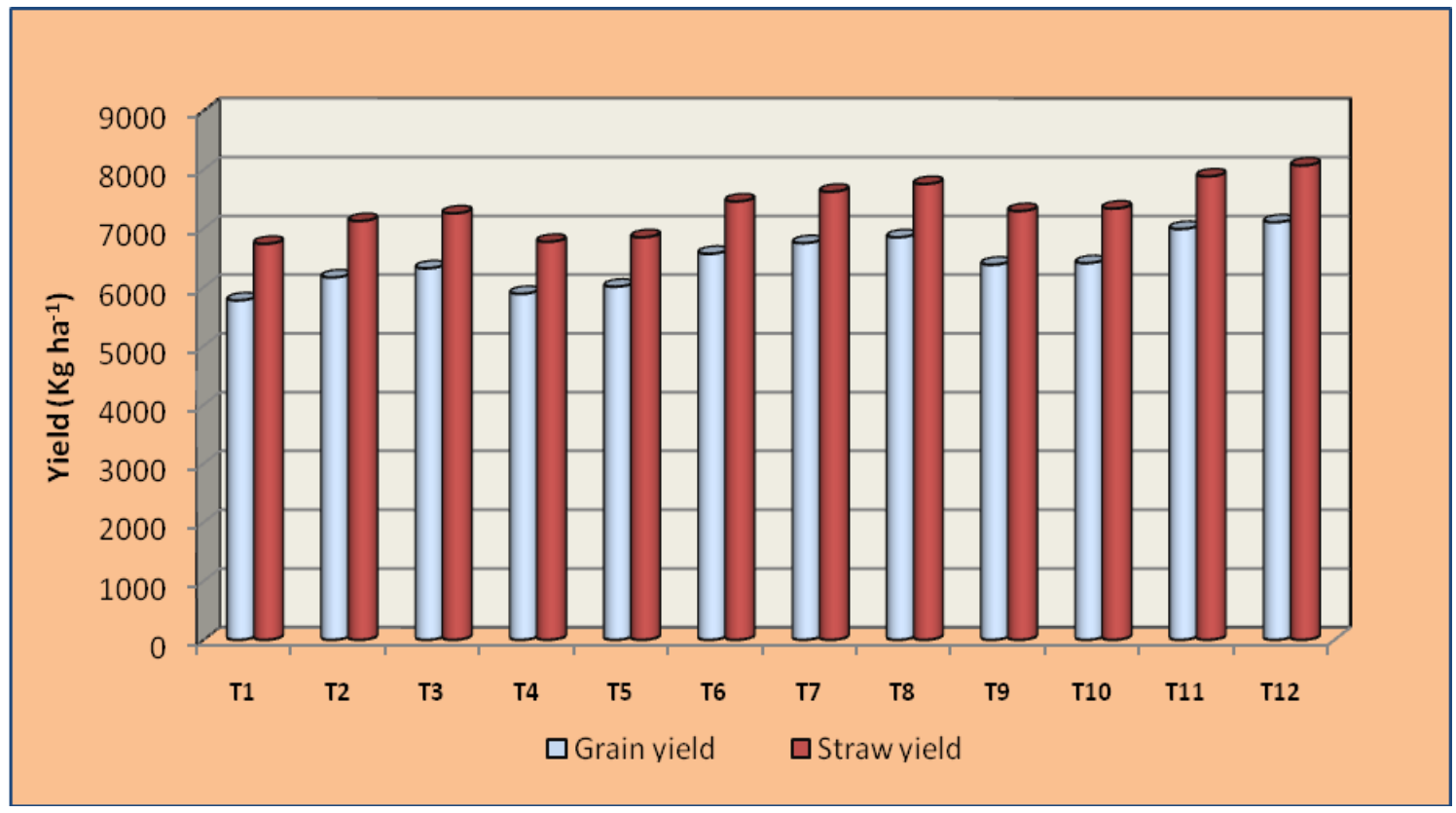


Table.3 Effect of zinc nutrition and green leaf manuring on grain and straw yield $\left(\mathrm{kg} \mathrm{ha}^{-1}\right)$ of rice

\begin{tabular}{|c|c|c|}
\hline Treatments & Grain yield $\left(\mathrm{kg} \mathrm{ha}^{-1}\right)$ & Straw yield $\left(\mathrm{kg} \mathrm{ha}^{-1}\right)$ \\
\hline $\mathrm{T}_{1}$ & 5776 & 6739 \\
\hline $\mathrm{T}_{2}$ & 6166 & 7127 \\
\hline $\mathrm{T}_{3}$ & 6322 & 7257 \\
\hline $\mathrm{T}_{4}$ & 5888 & 6773 \\
\hline $\mathrm{T}_{5}$ & 6009 & 6850 \\
\hline $\mathrm{T}_{6}$ & 6569 & 7460 \\
\hline $\mathrm{T}_{7}$ & 6751 & 7625 \\
\hline $\mathrm{T}_{8}$ & 6850 & 7757 \\
\hline $\mathrm{T}_{9}$ & 6384 & 7296 \\
\hline $\mathrm{T}_{10}$ & 6410 & 7339 \\
\hline $\mathrm{T}_{11}$ & 6991 & 7886 \\
\hline $\mathrm{T}_{12}$ & 7105 & 8072 \\
\hline SE d & 217 & 247 \\
\hline $\mathrm{CD}(\mathrm{P}=0.05)$ & 452 & 514 \\
\hline
\end{tabular}

Mythili et al., (2003); Khan et al., (2007); Singh and Shivay (2016) also reported favourable increase in yield attributes of rice with zinc application might be due to higher zinc uptake with zinc fertilization, resulting in higher biomass production and photosynthates accumulation and translocation to reproductive parts. Moreover addition of green leaf manure reduce the soil $\mathrm{pH}$, increased the soil aeration and the enhance availability of nutrients that influenced the higher yield attributes.

\section{Grain and straw yield of rice (Table 3)}

In cereal crops like rice, both grain and straw are the valuable economic parameters. They are nearly the function of yield components. In view of more number of productive tillers hill $^{-1}$, filled grains, panicle length, panicle weight and 1000 seed weight, the treatment $\mathrm{RDF}+$ green leaf manure $+\mathrm{ZnSO}_{4} 12.5 \mathrm{~kg} /$ ha as basal $+1 \%$ foliar spray had recorded maximum rice grain and straw yield (Fig. 2).

It was followed 100\% RDF + GLM @ 6.25 t / ha+ $\mathrm{ZnSO}_{4} @ 12.5 \mathrm{~kg} / \mathrm{ha}$ as basal+0.5\% foliar spray. The yield increased of these two treatments was not significantly different from many other treatments. The yield increase was due to increased crop growth and thus influenced the yield attributes by application of organic sources (GLM), recommended inorganic fertilizers such as NPK and zinc applied at entire crop growth stages. As well as it was due to the zinc nutrition, for several biochemical processes in the rice plant, such as cytochrome and nucleotide synthesis, auxin metabolism, chlorophyll production, enzyme activation and membrane integrity (IRRI, 2000) might have boosted the crop growth for the better production of biological as well as economical yield of rice. The current studies corroborated with earlier findings of Khan et $a l$. , (2007) and Singh and Shivay (2016).

From the above results, application of zinc as basal + foliar with green leaf manuring significantly influenced the yield parameters and yield. Addition of green leaf manuring favorably influenced the nutrient availability at all the stages of crop growth its leads to be better yield attribute and yield of rice. Hence, application of 100\% RDF + GLM @6.25 t / ha+ $\mathrm{ZnSO}_{4} @ 12.5 \mathrm{~kg} / \mathrm{ha}$ as basal+Foliar 
spray of $\mathrm{ZnSO}_{4} @ 1.0 \%$ is the best for obtain higher yield parameters and yield of rice.

\section{Acknowledgement}

With deep sense of gratitude, I bestow my earnest and sincere thanks to the Chairman of the advisory committee Dr. M. Hemalatha for her valuable peerless guidance and constant encouragement throughout the course of the investigation. Farm workers of agricultural college and research institute, Killikulam, who supported for all the cultural operations.

\section{References}

Arif, M., M.A. Chohan, S. Ali, R. Gul and S. Khan. 2006. Response of wheat to foliar application of nutrients. J. Agric. Biol. Sci., 1: 30-34.

Damodaran, V., B.K. Saren, N. Ravisankar, T. Subramani and N. BommayaSamy. 2014. Influence of management practices of System of Rice Intensification (SRI) on the physiological parameters, microbial dynamics and yield of rice in Island Ecosystem. J. Andaman Sci. Association, 19(2): 149-156.

Dobermann, A. and T. Fairhust. 2000. Rice: nutrient disorders and nutrient management. IRRI, Makati City, Philippines.

IRRI. 2000. Nutritional Disorders and
Nutrient Management in Rice. Manila, Philippines.

Khan, M.U., M. Qasim and I. Khan. 2007. Effect of $\mathrm{Zn}$ fertilizer on rice grown in different soils of dera Ismail Khan.Sarhad J. Agric., 23(4):10321040.

Mustafa, G., Enshanullah, N. Akbar, S.H. Qaisrani, A. Iqbal, H.Z. Khan, K. Jabran, A.A. Chattha, R. Trethowann, T. Chattha and B. M. Atta. 2011. Effect of zinc application on growth and yield of rice (Oryza sativa L.). Int. J. for Agro Veterinary and Medical sci., 5(6): 530535.

Mythili, S., K. Natarajan, and R. Kalpana. 2003. Zinc nutrition in rice - A Review. Agric. Rev., 24(2): 136-141.

Naik, S.K. and D.K. Das. 2007. Effect of split application of zinc on yield of rice (Oryza sativa L.) in an inceptisol. Arch. Agron. Soil Sci, 53: 305-313.

Savithri, P.R. Perumal and R. Natarajan. 1999. Soil and crop management technologies for enhancing rice production under micronutrient constraints. Nutrient Cycling in Agroecosystems, 53: 83-92.

Singh, A. and Y.S. Shivay. 2016. Effect of summer green manuring crops and zinc fertilizer sources on productivity, $\mathrm{Zn}$ uptake and economics of Basmati rice. J. Pl. Nutrition., 39(2): 204-218.

\section{How to cite this article:}

Prakash, P., M. Hemalatha and Joseph, M. 2017. Augmentation of Yield Parameters and Yield through Zinc and Green Leaf Manuring on Lowland Rice. Int.J.Curr.Microbiol.App.Sci. 6(7): 1438-1444. doi: https://doi.org/10.20546/ijcmas.2017.607.172 